\title{
Metazoan parasites of Plagioscion squamosissimus, an invasive species in the Tietê River, Sáo Paulo, Brazil
}

\author{
Parasitas metazoários de Plagioscion squamosissimus, uma espécie invasora no Rio Tietê, São Paulo \\ Ivan Moura Lapera ${ }^{1}$; Ana Carolina da Silva ${ }^{1}$; Bruno Marreto Canônico ${ }^{1}$; Gabriela de Farias Perezin ${ }^{1}$; \\ José Hairton Tebaldi ${ }^{1}$; Gabriela Pala ${ }^{2}$; Wilson Gómez Manrique ${ }^{3}$; Estevam Guilherme Lux Hoppe ${ }^{1 *}$

\begin{abstract}
${ }^{1}$ Departamento de Medicina Veterinária Preventiva e Reprodução Animal, Faculdade de Ciências Agrárias e Veterinárias, Universidade Estadual Paulista - UNESP, Jaboticabal, SP, Brasil

${ }^{2}$ Centro de Aquicultura da UNESP - CAUNESP, Universidade Estadual Paulista - UNESP, Jaboticabal, SP, Brasil

${ }^{3}$ Universidade Camilo Castelo Branco - Unicastelo, Descalvado, SP, Brasil
\end{abstract}

Received December 16, 2016

Accepted May 22, 2017

\begin{abstract}
This study focused on the characterization and analysis of communities and infra-communities of metazoan parasites of Plagioscion squamosissimus caught in Promissão Reservoir in the Tietê River in Borborema (21 $39^{\prime} 58^{\prime \prime}$ S, 49 $9^{\circ} 8^{\prime} 49^{\prime \prime}$ W), state of São Paulo, Brazil. Fifty adult specimens caught by professional fishermen in March 2015 were necropsied. The fish presented an average standard length of $25.2 \pm 2.2 \mathrm{~cm}$ and average weight of $328.82 \pm 89.03 \mathrm{~g}$. A total of 5,227 specimens of metazoan parasites were collected: 2,880 (55.1\%) adult Diplectanum piscinarius (Monogenoidea: Diplectanidae) and 2,347 (44.9\%) Austrodiplostomum compactum metacercariae (Digenea, Diplostomidae), both with 100\% prevalence and mean abundance of 57.6 and 46.9, respectively. Parasite diversity was low (species richness $=2$ ), with a Simpson index (D) equal to 0.505 , and low values of Brillouin $(\mathrm{HB}=0.687)$ and Margalef diversity $(\mathrm{I}=0.117)$ indices. Berger-Parker's index of dominance $(\mathrm{p}=0.551)$ indicated a slight dominance of the monogenean parasite $D$. piscinarius. There was a positive correlation, assessed by Pearson coefficient between parasite abundance of $D$. piscinarius and standard length $(r=0.43)$ and weight $(r=0.51)$ of hosts.
\end{abstract}

Keywords: Freshwater fish, South American silver croaker, parasite ecology, Austrodiplostomum compactum, Diplectanum piscinarius.

\section{Resumo}

O objetivo deste trabalho foi caracterizar e analisar as comunidades e infracomunidades de metazoários parasitos de corvinas capturadas no Reservatório de Promissão, Rio Tietê, município de Borborema ( $\left.21^{\circ} 67^{\prime} \mathrm{S}, 49^{\circ} 14^{\prime} \mathrm{O}\right)$, Estado de São Paulo. Foram examinados 50 espécimes, capturados por pescadores profissionais no mês de março de 2015, e os parasitas coletados foram quantificados, preparados e montados para identificação taxonômica e análise das comunidades de parasitos. Os peixes analisados no estudo apresentaram comprimento padráo médio de $25,2 \pm 2,2 \mathrm{~cm}$ e peso médio de 328,82 \pm 89,03 g. Foram coletados 5227 espécimes de parasitas metazoários, sendo $2880(55,1 \%)$ Diplectanum piscinarius (Monogenoidea: Diplectanidae) e 2347 (44,9\%) metacercárias de Austrodiplostomum compactum (Digenea, Diplostomidae), ambos com prevalência de 100\% e abundância parasitária de 57,6 e 46,9, respectivamente. Foi encontrada baixa diversidade parasitária (riqueza de espécies=2), com índice de Simpson (D) igual a 0,505 e baixos valores dos índices de Shannon $\left(\mathrm{H}^{\prime}=0,688\right)$ e de diversidade de Margalef $(\mathrm{I}=0,177)$. O índice de dominância de Berger-Parker $(\mathrm{d}=0,551)$ indicou uma leve dominância do monogenético D. piscinarius. Houve correlação positiva intermediária, avaliada pelo coeficiente de Pearson, entre a abundância parasitária de $D$. piscinarius e comprimento padrão $(r=0,43)$ e peso $(r=0,51)$ dos hospedeiros.

Palavras-chave: Peixe de água doce, corvina, ecologia parasitária, Austrodiplostomum compactum, Diplectanum piscinarius.

\footnotetext{
${ }^{*}$ Corresponding author: Estevam Guilherme Lux Hoppe. Departamento de Medicina Veterinária Preventiva e Reprodução Animal, Faculdade de Ciências Agrárias e Veterinárias, Universidade Estadual Paulista - UNESP, Via Prof. Paulo Donato Castellane, Km 05, CEP 14884-900, Jaboticabal, SP, Brasil. e-mail: hoppe@fcav.unesp.br; e.hoppe@gmail.com
} 


\section{Introduction}

Fish parasites are considered good models to study parasite ecology because it is easy to obtain replicas and to count all the members of these parasitic communities (ROHDE et al., 1995). In recent decades there has been a considerable increase in studies focusing on parasites and other aquatic pathogens, especially those that affect hosts with breeding and commercialization potential, given the significant increase in aquaculture in Brazil and worldwide (LUQUE, 2004).

It is important to study parasite biodiversity because these organisms play an important ecological role such as regulating the abundance or density of host populations, stabilizing food chains and structuring animal communities. Thus, adequate knowledge of parasite diversity is crucial for environmental management and conservation (LUQUE \& POULIN, 2007).

The analysis of fish parasite communities can provide important information about their hosts as well as the environment. Areas subjected to environmental impacts can cause changes in the population dynamics of fauna, especially of ichthyic fauna, which directly influences the populations of parasites as well as the prevalence and size of their infrapopulations (PAVANELLI et al., 2004).

The South American silver croaker Plagioscion squamosissimus (Heckel, 1840) (Osteichthyes: Sciaenidae) is native to the Amazon, Magdalena, Orinoco, and Essequibo Basins and also to the rivers of Guyana (CASATTI, 2003). This species was introduced in the state of São Paulo through the Pardo River, where it successfully established itself and spread to the Grande River. In 1972, this fish species made its way to the reservoirs of Ilha Solteira and Jupiá in the Paraná River, from where it reached the Tietê River. Currently, it is scattered throughout the Tietê River reservoir system (AGOSTINHO et al., 2005) and has gained relevant economic importance for local fishermen (CRUZ et al., 1990). Studies on the diet of the species characterize it as carnivorous, feeding preferentially on fish and shellfish (HAHN et al., 1999).

Various studies have reported 23 parasitic species in the South American silver croaker, including one cestode (WOODLAND, 1935), two digenetic (THATCHER, 1979; KOHN et al., 1995), 12 monogeneans (KRITSKY \& THATCHER, 1984; MARTINS et al., 2000a; KRITSKY \& BOEGER, 2002; BOEGER \& KRITSKY, 2009), two acanthocephalans (THATCHER, 1980; MELO et al., 2015), four nematodes (MORAVEC et al., 1993; MARTINS et al., 2000b; TAVARES et al., 2007) and two copepod crustaceans (AMADO \& ROCHA, 1996; THATCHER, 1998). Most of these studies were conducted in the Amazon and Paraná basins.

Several studies of fish parasites have been carried out in the Tietê River basin, most of which have reported only the occurrence of Austrodiplostomum compactum metacercariae (NOVAES et al., 2006; PAES et al., 2010a, b; ZICA et al., 2010). However, despite the economic and ecological importance of this river, parasitological studies remain scanty. Therefore, the objective of this study was to characterize and analyze communities and infracommunities of metazoan parasites of P. squamosissimus in Promissão Reservoir, in the Tietê River.

\section{Material and Methods}

\section{Study area}

This study was conducted in Promissão Reservoir (21 39'58'S, $\left.49^{\circ} 8^{\prime} 49^{\prime \prime} \mathrm{W}\right)$ in the Tietê River, located in the municipality of Borborema, state of São Paulo (Figure 1). The Tietê River divides the state of São Paulo in half, crossing it from east to west, and is fully inserted in the politicogeographical limits of the state (SMITH et al., 2002). It is abundant in fish in its middle and lower courses, where professional and amateur fishing are common. The course of the Tietê River follows an east-to-west direction towards the capital, and then changes direction towards the northwest (MARUYAMA et al., 2010).

For this study, 50 adult South American silver croakers were captured by professional fishermen using artisanal fishing nets. The fish were sedated in a benzocaine bath $(1: 500 \mathrm{v} / \mathrm{v})$ and then killed by medullary section. Each fish was wrapped individually, placed on ice and transported to the laboratory. Biometrics and taxonomic identification were performed as described by Casatti (2005). The specimens had an average standard length of $25.2 \pm 2.2 \mathrm{~cm}$ and weighed $328.82 \pm 89.03 \mathrm{~g}$.

\section{Parasitological methods}

For the parasitological analysis, mucus was scraped from the surface of the body and gills for microscopic inspection. Body surface, fins, nostrils, mouth, eyes, and the inner side of the membrane seals were carefully inspected for the presence of ectoparasites. The nostrils and mouth were washed with saline solution (sodium chloride $0.9 \%$ ) applied under pressure using wash bottles. The eyes were excised and washed in saline solution. Next, the gills were

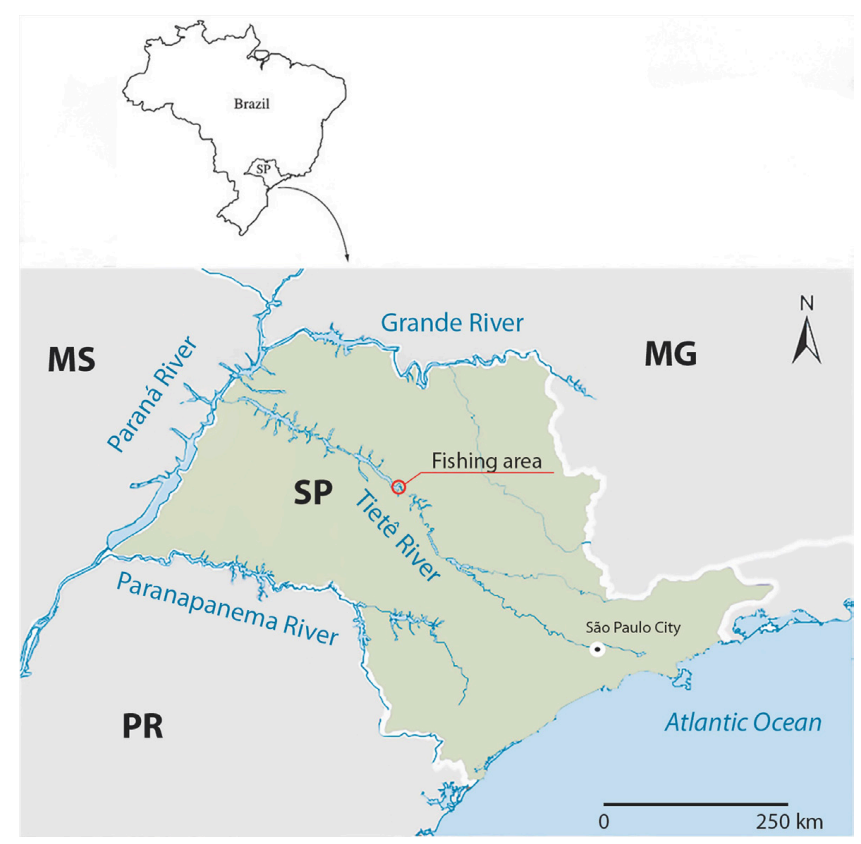

Figure 1. Location of the fishing area $\left(21^{\circ} 39^{\prime} 58^{\prime \prime} S, 49^{\circ} 8^{\prime} 49^{\prime \prime} \mathrm{W}\right)$ of this study in the Tietê River. 
removed and left gill was soaked in a formalin solution (1:4000) for two hours, then vigorously shaken. All the washing contents were individually placed in Petri dishes for stereomicroscopic evaluation. Evisceration was performed to examine the coelomic cavity. To collect the parasites, the organs were separated, placed in Petri dishes and examined under a stereomicroscope. Cuts were made in the muscles to search for encysted parasites. All the external and internal pathological findings were described in the necropsy record of each fish specimen.

The collected parasites were preserved in 5\% formalin solution and prepared in temporary mounts as described by Ergens (1969) and Eiras et al. (2006). Taxonomic identification was done as described by Kritsky \& Thatcher (1984) and Kohn et al. (1995). Vouchers were deposited in the Helminthological Collection of the Oswaldo Cruz Foundation (CHIOC/Fiocruz).

\section{Histopathology}

Samples of eyes and gills were collected and immediately fixed in $10 \%$ buffered formalin. The material was processed after performing routine methods, with cross sections $4 \mu \mathrm{m}$ and stained with Hematoxylin/Eosin. Images were recorded with a Olympus BX-51 microscope equipped with an Olympus Q-Color 3 digital camera.

\section{Ecological methods}

The total number of each parasite species was determined by total counting. The indices of prevalence of infestation, average intensity and average abundance were calculated for the parasite species found in the fish, using the ecological terminology employed by Bush et al. (1997). To analyze the infracommunities, the following parameters were determined according to Magurran (2004): species richness, Margalef diversity index (I), Berger-Parker dominance index (d), Brillouin index (HB) and Simpson index (D).

\section{Statistical analyses}

The effects of length and weight of the hosts were evaluated using the Pearson correlation coefficient and Spearman rank correlation coefficient (ZAR, 1996). Prior to the statistical analysis, the data normality was assessed with the Kolmogorov-Smirnov test at a $5 \%$ level of significance. Comparisons were made of the homoscedastic data using Pearson's correlation coefficient ( $r$ ) and of the heteroscedastic data using Spearman's rank correlation coefficient (rs).

\section{Ethical aspects}

All the procedures employed in this study were approved by the Ethics Committee on Animal Use of FCAV/UNESP under Protocol no. 10955/14 and by the Chico Mendes Institute for Biodiversity Conservation - ICMBio (SISBIO 44747).

\section{Results}

All the South American silver croakers of this study were parasitized. A total of 5,227 metazoan parasite specimens were collected, with an average of 104.54 parasites/fish, comprising 2,880 (55.1\%) monogeneans Diplectanum piscinarius, and 2,347 (44.9\%) Austrodiplostomum compactum digenetic metacercariae. Table 1 lists the prevalence, intensity range, mean intensity and mean abundance of each of the parasite species, in addition to the infection sites.

\section{Austrodiplostomum compactum (Lutz, 1928)}

\section{(Digenea: Diplostomidae; CHIOC 38102)}

The metacercariae found in the eyes of P. squamosissimus (Figure 2) presents an elongated, dorsoventrally flattened, foliaceous body, slightly concave on the ventral side and convex in the anterior region. The posterior region features a small conical protuberance of varied size. The subterminal oral sucker is flanked by two pseudo-suckers. The pharynx is oval, the esophagus is short, and glandular cells are visible in most of the anterior region of the metacercariae. Small, underdeveloped gonads are visible close to the oval tribocytic organ. The intestinal ceca extend towards the posterior region and the acetabulum is small. Table 2 compares the characteristics observed in this study with data reported by other authors.

\section{Diplectanum piscinarius Kritsky and Thatcher, 1984 (Monogenoidea: Diplectanidae; CHIOC 38103)}

These monogeneans (Figure 3) have an elongated body, poorly developed cephalic lobes, with four ocelli, a subovate squamodisc, a wide and elongated peduncle, a haptor with similar hooks, two pairs of non-similar anchors, a ventral bar with long tapered ends marked by an anteromedial constriction and absence of posteromedial projection, and a long dorsal bar with medial termination. The copulatory complex is funnel-shaped, lacking an accessory piece. Table 3 describes the morphometrics observed in this study.

\section{Ecological indicators}

A species richness of 2 was observed, and low species diversity was evidenced by a high Simpson $(\mathrm{D}=0.505)$ index and low Brillouin $(\mathrm{HB}=0.687)$ and Margalef diversity $(\mathrm{I}=0.117)$ indices.

Table 1. Indicators of parasite infection observed in South American silver croakers collected in the Promissão Reservoir, Tietê River, SP, Brazil.

\begin{tabular}{|c|c|c|c|c|c|}
\hline Parasite & Prevalence (\%) & Intensity Variation & Mean Intensity & Mean Abundance & Site of Infection \\
\hline $\begin{array}{l}\text { Monogenea } \\
\text { Diplectanum piscinarius }\end{array}$ & 100 & $6-172$ & $57.6 \pm 33.2$ & $57.6 \pm 33.2$ & gills \\
\hline $\begin{array}{l}\text { Digenea } \\
\text { Austrodiplostomum compactum } \\
\text { (metacercariae) }\end{array}$ & 100 & $2-206$ & $46.9 \pm 46.8$ & $46.9 \pm 46.8$ & eyes \\
\hline
\end{tabular}




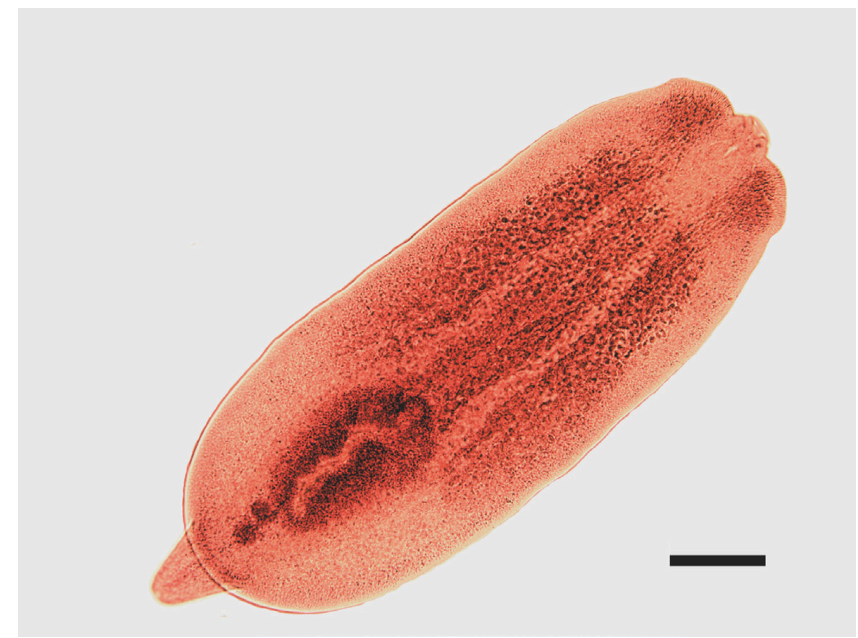

Figure 2. Semi-permanent Hoyer mounting of Austrodiplostomum compactum, stained with Mayer's Carmalumen. BAR $=200 \mu \mathrm{m}$.

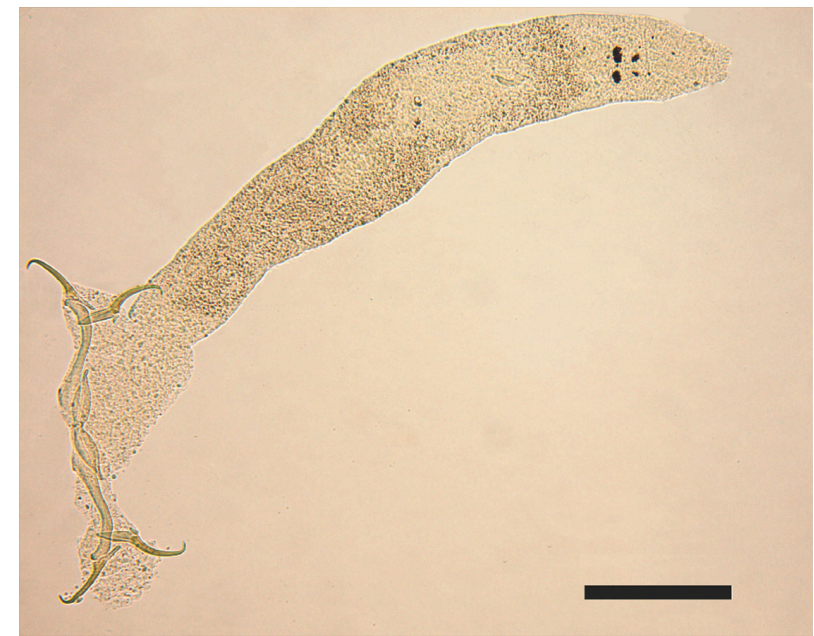

Figure 3. Semi-permanent ammonium picrate-glycerin mounting of Diplectanum piscinarius. $\mathrm{BAR}=100 \mu \mathrm{m}$.

Table 2. Morphometric data of Austrodiplostomum compactum metacercariae obtained from South American silver croakers collected in the Promissão Reservoir, Tietê River, São Paulo, and measurements reported by other authors.

\begin{tabular}{|c|c|c|c|c|c|c|c|c|}
\hline \multirow{2}{*}{ Authors } & \multicolumn{2}{|c|}{ Body } & \multicolumn{2}{|c|}{ Oral sucker } & \multicolumn{2}{|c|}{ Pharynx } & \multicolumn{2}{|c|}{ Tribocytic Organ } \\
\hline & length & width & length & width & length & width & length & width \\
\hline $\begin{array}{l}\text { Kohn et al. } \\
(1995)^{*}\end{array}$ & $\begin{array}{c}1,470-2,740 \\
(2,170)\end{array}$ & $\begin{array}{l}600-1180 \\
(970)\end{array}$ & $41-97(77)$ & $56-116(79)$ & $64-94(83)$ & $45-79(60)$ & $326-650(507)$ & $251-500(370)$ \\
\hline $\begin{array}{l}\text { Santos et al. } \\
(2002)^{*}\end{array}$ & $\begin{array}{c}880-1,840 \\
(1,434)\end{array}$ & $400-792(611)$ & $44-90(65)$ & $40-64(52)$ & $50-64(62)$ & $40-60(49)$ & $200-600(285)$ & $160-232(182)$ \\
\hline $\begin{array}{l}\text { Novaes et al. } \\
(2006)^{*}\end{array}$ & $\begin{array}{c}1,584-1,947 \\
(1,800)\end{array}$ & $537-709(642)$ & $45-83(59)$ & $54-77(68)$ & $53-73(61)$ & $50-64(56)$ & $422-434(428)$ & $220-319(258)$ \\
\hline $\begin{array}{l}\text { Yamada et al. } \\
(2008)^{*}\end{array}$ & $\begin{array}{c}680-1,190 \\
(1,037)\end{array}$ & $\begin{array}{c}310-1010 \\
\quad(568)\end{array}$ & $19-60(46)$ & $29-60(50)$ & $36-96(60)$ & $14-55(40)$ & $91-324(236)$ & $85-228(152)$ \\
\hline $\begin{array}{l}\text { Paes et al. } \\
(2010 a)^{*}\end{array}$ & $\begin{array}{c}1,301-2,386 \\
(1,911)\end{array}$ & $482-854(678)$ & $51-87(71)$ & $51-92(73)$ & 49-84 (69) & $45-74(58)$ & $205-554(401)$ & $127-347(246)$ \\
\hline $\begin{array}{l}\text { Zica et al. } \\
(2010)^{*}\end{array}$ & $\begin{array}{c}1,342-2,007 \\
(1,708)\end{array}$ & $481-711(601)$ & $41-81(59)$ & $47-89(67)$ & $51-99(72)$ & $35-66(51)$ & $348-460(400)$ & $91-199(145)$ \\
\hline $\begin{array}{l}\text { Present } \\
\text { Study* }\end{array}$ & $\begin{array}{c}1,450-2,166 \\
(1,789)\end{array}$ & $566-902(683)$ & $57-86(72)$ & 49-97 (76) & $61-99(80)$ & $41-75(58)$ & $302-492(405)$ & $193-319(256)$ \\
\hline
\end{tabular}

*Measurements in $\mu \mathrm{m}$, mean values in parenthesis.

Table 3. Morphometric data of Diplectanum piscinarius obtained from South American silver croakers collected in the Promissão Reservoir, Tietê River, SP, Brazil, in comparison to literature.

\begin{tabular}{lccc}
\hline & & \multicolumn{2}{c}{ Authors } \\
\cline { 3 - 4 } Number of specimen & Kritsky \& Thatcher (1984)* & Present Study* \\
Body & length & 13 & $599-928(762)$ \\
& width & $537-869(728)$ & $76-135(103)$ \\
Haptor & length & $69-98(86)$ & $80-103(82)$ \\
& width & $81-92(86)$ & $212-262(237)$ \\
Ventral Anchor & length & $191-228(206)$ & $67-78(72)$ \\
Dorsal Anchor & length & $66-77(71)$ & $60-68(63)$ \\
Ventral Bar & length & $59-68(64)$ & $84-104(93)$ \\
Dorsal Bar & length & $77-91(84)$ & $88-107(96)$ \\
Complex Copulatory organs & length & $76-97(88)$ & $24-33(29)$ \\
\hline
\end{tabular}


The Berger-Parker dominance index (d) was 0.551, indicating a slight dominance of $D$. piscinarius.

\section{Host-parasite relationship}

Diplectanum piscinarius specimens were found in some histological sections of the gills. The main lesions observed were epithelial hyperplasia of primary and secondary gill lamellae, dilation of central venous sinus, edema, mononuclear and eosinophilic inflammatory infiltration, expansion of secondary lamellae with congestion, detachment of the epithelial lining of the secondary lamellae, telangiectasia and total fusion of secondary lamellae. The presence of cells with pyknotic nucleus and translucent cytoplasm indicative of necrosis was also observed (Figure 4).

No damage associated with parasitism by $A$. compactum was found in the eyes, despite the presence of the parasite in the histological sections (Figure 5). Macroscopically, 34 of the South

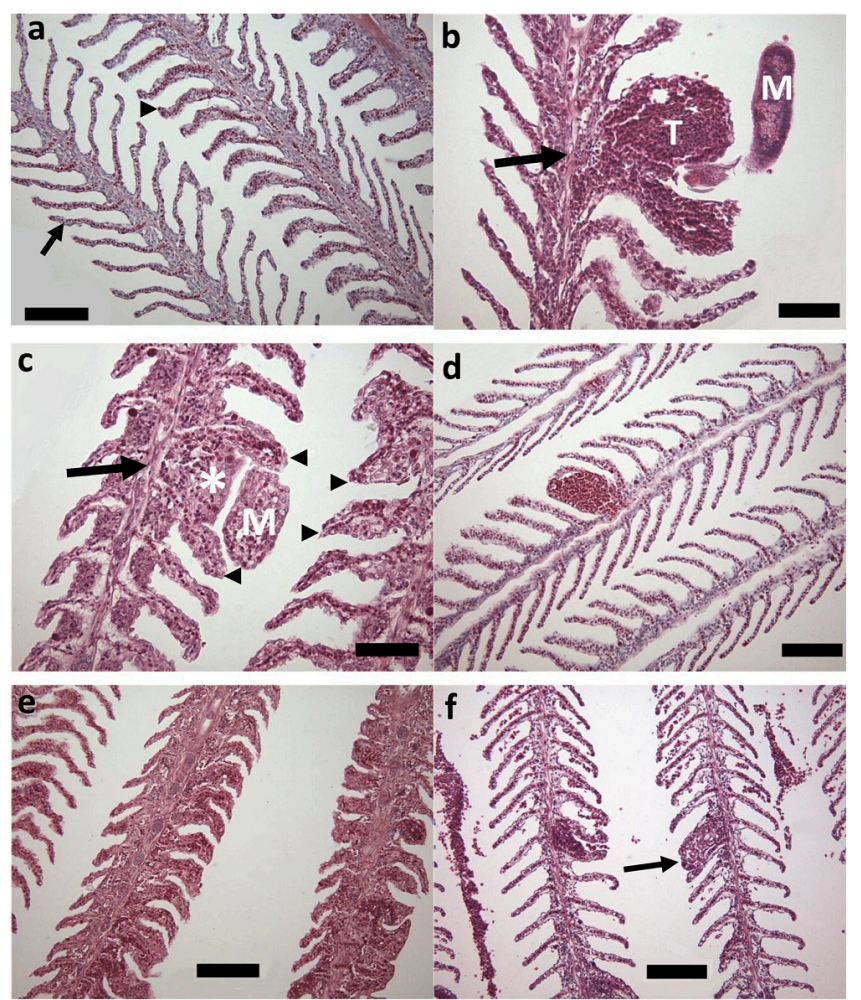

Figure 4. Photomicrographs of the gills. (a) Normal tissue (arrow), blood accumulation in the secondary gill lamellae (arrowhead). HE, $\mathrm{BAR}=100 \mu \mathrm{m}$. (b) Monogenea (M), telangiectasia (T), dilation of the central venous sinus (arrow), epithelial hyperplasia of secondary gill lamellae. $\mathrm{HE}, \mathrm{BAR}=50 \mu \mathrm{m}$. (c) Epithelial hyperplasia of secondary gill lamellae (arrowhead), epithelial hyperplasia of primary gill lamellae $\left(^{*}\right)$, inflammatory infiltration. HE, BAR $=50 \mu \mathrm{m}$. (d) Presence of cells with pyknotic nucleus and translucent cytoplasm indicative of necrosis, detail of the fixation of Monogenea (M), detachment of the epithelial lining of secondary lamellae (arrow), edema $\left(^{*}\right)$. HE, $\mathrm{BAR}=20 \mu \mathrm{m}$. (e) Intense epithelial hyperplasia of secondary gill lamellae. HE, $B A R=100 \mu \mathrm{m}$. (f) Total fusion of secondary lamellae (arrow). HE, BAR=100 $\mu \mathrm{m}$.
American silver croakers showed lens opacity in at least one eye, although there were no histopathological signs of cataracts.

Only D. piscinarius presented a positive intermediate correlation between standard length and weight and parasite abundance, presenting statistically significant differences by Pearson's correlation coefficient $(\mathrm{p}<0.05)$. For the digenetic parasites, the correlation between standard length and weight and parasite abundance was evaluated by Spearman's rank correlation coefficient. No significant degree of correlation was found between the data $(\mathrm{p}>0.05)$ (Table 4).

\section{Discussion}

Although the literature describes several types of parasites for P. squamosissimus (WOODLAND, 1935; THATCHER, 1979; THATCHER, 1980; KRITSKY \& THATCHER, 1984; MORAVEC et al., 1993; KOHN et al., 1995; AMADO \& ROCHA, 1996; THATCHER, 1998; MARTINS et al., 2000a, b; KRITSKY \& BOEGER, 2002; TAVARES et al., 2007; BOEGER \& KRITSKY; 2009; MELO et al., 2015), low diversity and richness of parasites in South American silver croakers were observed in this study. This can be attributed to the fact that most reports refer to studies conducted in regions where the species occurs endemically. Low parasitic diversity was also found in studies carried out in places where this fish species was introduced, such as the Upper Paraná River floodplain (TAKEMOTO et al., 2009), and the Volta Grande Reservoir in the state of Minas Gerais, Brazil (MARTINS et al., 2000a, b; MARTINS et al., 2002). Other studies conducted on this fish from the Tietê River only reported the occurrence of digenetic parasites (PAES et al., 2010a, b), which were also found in this study.

Most reports on $A$. compactum in $P$. squamosissimus describe high prevalence rates, often over 90\% (KOHN et al., 1995; MARTINS et al., 2002; SANTOS et al., 2002; MACHADO et al., 2005; PAES et al., 2010a,b; RAMOS et al., 2014). Thus, in view of the $100 \%$ prevalence rate and high average parasite intensity

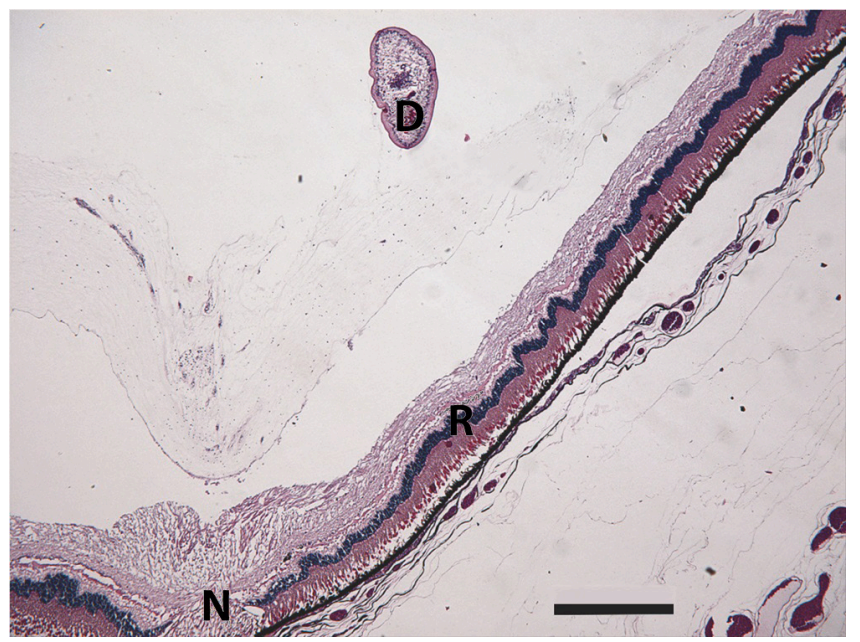

Figure 5. Photomicrograph of a fish eye. Presence of the digenetic parasite (D), optic nerve (N) and retina (R). HE, BAR=500 $\mu \mathrm{m}$. 
Table 4. Values of the Spearman rank correlation coefficient (rs) and the Pearson correlation coefficient (r).

\begin{tabular}{cccccc}
\hline & \multicolumn{2}{c}{ SL-Abundance correlation } & & \multicolumn{2}{c}{ W - Abundance correlation } \\
\cline { 2 - 3 } \cline { 5 - 6 } & D. piscinarius & A. compactum & & D. piscinarius & A. compactum \\
rs & - & 0.1956 & - & 0.2279 \\
$\mathrm{p}$ & - & 0.1733 & - & 0.1114 \\
$r$ & $0.4331^{*}$ & - & $0.5077^{*}$ & - \\
$\mathrm{p}$ & 0.0017 & - & 0.0002 & - \\
\hline
\end{tabular}

*significant values; (SL) standard length; (W) weight; $\mathrm{p}$ = level of significance (0.05).

(46.9), represented by up to 206 parasites in a single host, the data obtained here are similar to the findings of other authors (KOHN et al., 1995; SANTOS et al., 2002; MACHADO et al., 2005; PAES et al., 2010a, b), confirming the parasite's preference for croakers, as reported by Yamada et al. (2008).

With regard to D. piscinarius, Tavernari et al. (2005) reported a prevalence rate of $97 \%$ and an average intensity of 31.8 parasites per host, which is very similar to the present study. The high prevalence rate is like explained by the short life cycle of diplectanids (IANNACONE et al., 2000) and by the fact that the parasite's eggs stick to the lining of the gills or to tegument, causing constant reinfection of the host (JARA, 1998).

The high prevalence rate of parasites found here may be ascribed to the abnormally long dry season lasting from January to October, which occurred before the completion of this study. In the first 10 months of 2014, the recorded average rainfall in the study area was $45 \%$ lower than the average in the same period in 2013 (CIIAGRO, 2015). In this study area, the rainy season usually occurs from October to April and the dry season from May to September, with an average annual rainfall of 1000 to $1300 \mathrm{~mm}$ (CASTRO et al., 2008). According to the National Electricity System Operator (ONS, 2015), the Promissão Reservoir was at less than one third of its net volume, ranging from 20 to $36 \%$ during practically the entire year of 2014 . This low volume of water may have increased the density of the fish population, resulting in the high prevalence rates and intensities of infection observed in this study. Noteworthy to say, other parasites were not favored by the increased fish population density.

In Brazil, the first description of $A$. compactum was made by Kohn et al. (1995), and since then, this parasite has been reported in over 30 species, indicating low host specificity (RAMOS et al., 2014). The presence of this parasite in fish eyes can cause total or partial loss of vision, making the fish more vulnerable to predation and facilitating the parasite's transmission to the definitive host (EIRAS, 1994).

Earlier studies have reported a positive correlation between A. compactum infection intensity and the host's standard weight and length (MACHADO et al., 2005; PAES et al., 2010b). However, this study did not find a significant correlation between infection by this parasite and the host's characteristics (standard length: $r s=0.195, \mathrm{P}=0.1733$; weight: $\mathrm{rs}=0.2279 ; \mathrm{P}=0.1114$ ). Kennedy \& Burrough (1977) stated that the host's length and the parasite intensity of Diplostomum spp. are rarely correlated, and that in some cases there may be a negative correlation, depending on the longevity of metacercariae species. Thus, if the species' longevity is low, new infections are offset by mortality rates of older parasites (KENNEDY \& BURROUGH, 1978). In this study, the parasite intensity and/or chronicity of infection were most likely insufficient to reduce the hosts' visual acuity to the point that would render them more susceptible to predation. As the animals of this study showed no signs of associated disease, the infection may have been recent, which would explain the absence of a correlation between infection and the host's characteristics.

The occurrence of this parasite infecting several species of fish in different aquatic ecosystems suggests that it was introduced along with croaker fish and that it found the right conditions to develop its cycle, adapting to the new ecosystem and to the fish in it (MACHADO et al., 2005; YAMADA et al., 2008; TAKEMOTO et al., 2009). Therefore, studies regarding the impact of the infection in native fish should be developed, in order to evaluate a possible environmental impact of its introduction in new areas. Moreover, infection by diplostomids in fish may be a matter of public health concern because of their zoonotic potential (EIRAS, 1994).

Diplectanum piscinarius was first described parasitizing the gills of P. squamosissimus collected in Lake Januáca in Manaus, state of Amazonas, Brazil (KRITSKY \& THATCHER, 1984). Although monogenetic parasites present a higher degree of specificity than other groups of parasites (BUSH et al., 2001), D. piscinarius has also been reported in Pachyurus bonariensis (BRAGA et al., 2014). Massive infections with this parasite may lead to hemorrhage, inflammation and hyperplasia of the gill epithelium, increased mucus production, and lamellar fusion, which are harmful to the breathing process (WOO, 2006).

Unlike $A$. compactum, infection by $D$. piscinarius showed a positive correlation between parasitic intensity and standard length $(\mathrm{r}=0.4331 ; \mathrm{P}=0.0017)$ and weight $(\mathrm{r}=0.5077 ; \mathrm{P}=0.0002)$ of the hosts, a finding that had not previously been reported (MARTINS et al., 2000a; TAVERNARI et al., 2005). The infestation by Diplectanum sp. in Cynoscion analis, another Sciaenidae fish, showed a positive correlation between parasite intensity and standard length of the host (IANNACONE et al., 2000). This data indicates a cumulative effect of the infection by $D$. piscinarius, possibly due to the larger size of the host (larger surface for parasitism) and/or longer exposure to the parasite (TAVERNARI et al., 2005).

The ecological and histopathological data obtained here indicates that the parasites and parasite intensities found in this study cause only minor injuries. However, such lesions demonstrate the pathogenic potential of these parasites, particularly of monogenean parasites. 


\section{Conclusions}

This study allowed us to infer that monogenean and digenetic parasites are prevalent in the parasite community of South American silver croakers in the Promissão Reservoir, since the community comprises only $D$. piscinarius and $A$. compactum. It can also be stated that the hosts' weight and standard length influence the intensity of parasitism by $D$. piscinarius in P. squamosissimus, with an intermediate positive correlation for both biometric parameters. Future studies are necessary to determine if this parasitological status will be permanent after the severe drought or if the parasitefauna will increase in diversity over the years.

\section{Acknowledgements}

The authors gratefully acknowledge the financial support of CAPES, Brazil's Federal Agency for the Support and Improvement of Higher Education, and one of the anonymous reviewers for the valuable commentaries and suggestions.

\section{Conflict of Interest}

The authors hereby declare that they have no conflict of interest.

\section{References}

Agostinho AA, Pelicice FM, Julio HF Jr. Introdução de espécies de peixes em águas continentais brasileiras: uma síntese. In: Rocha O, Espindola ELG, Fenerich-Verani N, Verani JR, Rietzler AC, editors. Espécies invasoras em águas doces: estudos de caso e propostas de manejo. São Carlos: Editora da Universidade Federal de São Carlos; 2005. p. 13-23.

Amado MAPM, Rocha CEF. Therodamas tamarae, a new species of copepod (Poecilostomatoida: Ergasilidae) parasitic on Plagioscion squamosissimus (Heckel) from the Araguaia River, Brazil; with a key to the species of the genus. Hydrobiologia 1996; 325(1): 77-82. http://dx.doi.org/10.1007/ BF00023669.

Boeger WA, Kritsky DC. Neotropical Monogenoidea. 54. Proposal of Aetheolabes n. g. (Dactylogyrinea: Diplectanidae), with the description of A. goeldiensis n. sp. from the gills of 'pescada' Plagioscion sp. (Teleostei: Sciaenidae) in Brazil. Syst Parasitol 2009; 74(2): 137-142. PMid:19731097. http://dx.doi.org/10.1007/s11230-009-9193-7.

Braga MP, Araújo SBL, Boeger WA. Patterns of interaction between Neotropical freshwater fishes and their gill Monogenoidea (Platyhelminthes). Parasitol Res 2014; 113(2): 481-490. PMid:24221891. http://dx.doi. org/10.1007/s00436-013-3677-8.

Bush AO, Fernández JC, Esch GW, Seed R. Parasitism: the diversity and ecology of Animal Parasites. Cambridge: Cambridge University Press; 2001.

Bush AO, Lafferty KD, Lotz JM, Shostak AW. Parasitology meets ecology on its own terms: Margolis et al. revisited. J Parasitol 1997; 83(4): 575583. PMid:9267395. http://dx.doi.org/10.2307/3284227.

Casatti L. Family Sciaenidae (Drums or croakers). In: Reis RE, Kullander SO, Ferraris CJ Jr, editors. Check list of the freshwater fishes of South and Central America. Porto Alegre: Edipucrs; 2003. p. 598-602.
Casatti L. Revision of the South American freshwater genus Plagioscion (Teleostei, Perciformes, Sciaenidae). Zootaxa 2005; 1080(1): 39-64. http://dx.doi.org/10.11646/zootaxa.1080.1.4.

Castro PMG, Maruyama LD, Campos EC, Paiva P, Spigolon JR, Menezes LCB. Mapeamento da pesca artesanal ao longo do Médio e Baixo Rio Tietê (Sáo Paulo, Brasil). Sér Relat Téc 2008; 33: 1-34.

Centro Integrado de Informaçóes Agrometeorólogicas - CIIAGRO. [online]. 2015 [cited 2015 Aug 20]. Available from: http://www.ciiagro. sp.gov.br/ciiagroonline/

Cruz JA, Moreira JA, Verani JR, Girard L, Torloni CEC. Levantamento da Ictiofauna e aspectos da dinâmica de população de algumas espécies do reservatório de Promissão, SP (1 a Etapa). São Paulo: CESP/UFSCar; 1990.

Eiras JC, Takemoto RM, Pavanelli GC. Métodos de estudos e técnicas laboratoriais em parasitologia de peixes. Maringá: EDUEM; 2006.

Eiras JC. Elementos de Ictioparasitologia. Porto: Fundação Eng. António de Almeida; 1994.

Ergens R. The suitability of ammonium picrate: glycerin in preparing slides of lower Monogenoidea. Folia Parasitol (Praha) 1969; 16(4): 320.

Hahn NS, Loureiro VE, Delariva RL. Atividade alimentar da curvina Plagioscion squamosissimus (Heckel, 1840) (Perciformes, Sciaenidae) no rio Paraná. Acta Sci Biol Sci 1999; 21(2): 309-314.

Iannacone J, Mejía W, Alcócer F, Briones G, Román A. Características de La infestación de Diplectanum sp. (Monogenea: Monopisthocotylea: Diplectanidae) en el ayanque Cynoscion analis Jenyns (Pisces: Teleostei: Sciaenidae). Rev Peru Biol 2000; 7(1): 44-54.

Jara CA. Prevalencia e intensidad de parasitismo por helmintos en cuatro especies de peces de la zona norte del mar peruano. Rev Peru Parasitol 1998; 13(1): 76-83.

Kennedy CR, Burrough R. The population biology of two species of eyefluke, Diplostomum gasterostei and Tylodelphys clavata, in perch.J Fish Biol 1977; 11(6): 619-633. http://dx.doi.org/10.1111/j.1095-8649.1977. tb05720.x.

Kennedy CR, Burrough R. Parasites of trout and perch in Malham Tarn. Fld Stud 1978; 4: 617-629.

Kohn A, Fernandes BMM, Baptista-Farias MFD. Metacercariae of Diplostomum (Austrodiplostomum) compactum (Trematoda, Diplostomidae) in the eyes of Plagioscion squamosissimus (Teleostei, Sciaenidae) from the reservoir of the hydroelectric power station of Itaipu, Brazil. Mem Inst Oswaldo Cruz 1995; 90(3): 341-344. http://dx.doi.org/10.1590/ S0074-02761995000300005.

Kritsky DC, Boeger WA. Neotropical Monogenoidea. 41: New and previously described species of Dactylogyridae (Platyhelminthes) from the gills of marine and freshwater perciform fishes (Teleostei) with proposal of a new genus and a hypothesis on phylogeny. Zoosystema 2002; 24(1): 7-40.

Kritsky DC, Thatcher VE. Neotropical Monogenea. 6: Five species of Diplectanum (Diplectanidae) from freshwater teleosts, Plagioscion spp. (Sciaenidae), in Brazil. Proc Biol Soc Wash 1984; 97(2): 432-441.

Luque JL, Poulin R. Metazoan parasite species richness in Neotropical fishes: hotspots and the geography of biodiversity. Parasitology 2007; 134(6): 865-878. PMid:17291392. http://dx.doi.org/10.1017/ S0031182007002272. 
Luque JL. Biologia, Epidemiologia e Controle de parasitos de peixes. Rev Bras Parasitol Vet 2004; 13(S1): 161-164.

Machado PM, Takemoto RM, Pavanelli GC. Diplostomum (Austrodiplostomum) compactum (Lutz, 1928) (Platyhelminthes, Digenea) metacercariae in fish from the floodplain of the Upper Paraná River, Brazil. Parasitol Res 2005; 97(6): 436-444. PMid:16151731. http://dx.doi.org/10.1007/ s00436-005-1483-7.

Magurran AE. Measuring biological diversity. Oxford: Blackwell Science; 2004.

Martins ML, Fujimoto RY, Moraes FR, Andrade PM, Nascimento AA, Malheiros EB. Description and prevalence of Thynnascaris sp. Larvae Dollfus, 1933 (Nematoda: Anisakidae) in Plagioscion squamosissimus Heckel, 1840 from Volta Grande Reservoir, State of Minas Gerais, Brazil Rev Bras Biol 2000b; 60(3): 519-526. PMid:11188878. http://dx.doi. org/10.1590/S0034-71082000000300017.

Martins ML, Fujimoto RY, Moraes FR. Prevalence and seasonality of Diplectanum piscinarius Kritsky and Thatcher 1984 (Monogenoidea) in the gills of Plagioscion squamosissimus Heckel 1840 (Sciaenidae) from Volta Grande Reservoir, MG, Brazil. Rev Bras Parasitol Vet 2000a; 9(2): 105-107.

Martins ML, Paiva AMFC, Fujimoto RY, Schalch SHC, Colombano NC. Prevalência, sazonalidade e intensidade de infecção por Diplostomum (Austrodiplostomum) compactum Lutz, 1928 (Digenea, Diplostomidae), em peixes do reservatório de Volta Grande, Estado de Minas Gerais, Brasil. Acta Sci Biol Sci 2002; 24(2): 469-474.

Maruyama LS, Castro PMG, Paiva P, Silva MEPA, Silva KM. Produção pesqueira do Baixo Rio Tietê, nos anos de 2003-2004. Sér Relat Téc 2010; 45: 1-16.

Melo FTV, Costa PAFB, Giese EG, Gardner SL, Santos JN. A description of Neoechinorhynchus (Neoechinorhynchus) veropesoi $\mathrm{n}$. sp. (Acanthocephala: Neoechinorhynchidae) from the intestine of the silver croaker fish Plagioscion squamosissimus (Heckel, 1840) (Osteichthyes: Sciaenidae) off the east coast of Brazil. J Helminthol 2015; 89(1): 34-41. PMid:26262594. http://dx.doi.org/10.1017/S0022149X13000564.

Moravec F, Kohn A, Fernandes BMM. Nematode parasites of fishes of the Paraná River, Brazil. Part 2. Seuratoidea, Ascaridoidea, Habronematoidea and Acuaroidea. Folia Parasit 1993; 40(2): 115-134.

Novaes JLC, Ramos IP, Carvalho ED, Silva RJ. Metacercariae of Diplostomum compactum Lutz, 1928 (Trematoda, Diplostomidae) in the eyes of acara Geophagus brasiliensis Quoy \& Gaimard, 1824 (Teleostei, Cichlidae) from Barra Bonita Reservoir - São Paulo, Brazil. Arq Bras Med Vet Zootec 2006; 58(6): 1229-1231. http://dx.doi.org/10.1590/ S0102-09352006000600037.

Operador Nacional do Sistema Elétrico - ONS. [online]. 2015 [cited 2015 Sep 29]. Available from: http://www.ons.org.br/

Paes JVK, Carvalho ED, Silva RJ. Infection by Austrodiplostomum compactum metacercariae in fish from the Nova Avanhandava reservoir, Tietê river, São Paulo State, Brazil. Acta Sci Biol Sci 2010a; 32(3): 273-278.

Paes JVK, Carvalho ED, Silva RJ. Infection levels of Austrodiplostomum compactum (Digenea, Diplostomidae) metacercariae in Plagioscion squamosissimus (Teleostei, Sciaenidae) from the Nova Avanhandava reservoir, São Paulo State, Brazil. J Helminthol 2010b; 84(3): 284-291. PMid:19889255. http://dx.doi.org/10.1017/S0022149X09990617.
Pavanelli GC, Machado MH, Takemoto RM, Guidelli GM, Lizama MAP. Helminth fauna of the fishes: diversity and ecological aspects. In: Thomaz SM, Agostinho AA, Hahn NS, editors. The Upper Paraná River and its floodplain: Physical aspects, Ecology and Conservation. Leiden: Backhuys Publishers; 2004. p. 309-329.

Ramos IP, Franceschini L, Zica ÉOP, Carvalho ED, Silva RJ. The influence of cage farming on infection of the corvine fish Plagioscion squamosissimus (Perciformes: Sciaenidae) with metacercariae of Austrodiplostomum compactum (Digenea: Diplostomidae) from the Chavantes reservoir, São Paulo State, Brazil. J Helminthol 2014; 88(3): 342-348. PMid:23628163. http://dx.doi.org/10.1017/S0022149X13000229.

Rohde K, Hayward C, Heap M. Aspects of the ecology of metazoan ectoparasites of marine fishes. Int J Parasitol 1995; 25(8): 945-970. PMid:8550295. http://dx.doi.org/10.1016/0020-7519(95)00015-T.

Santos RS, Pimenta FDA, Martins ML, Takahashi HK, Marengoni NG. Metacercarias de Diplostomum (Austrodiplostomum) compactum Lutz, 1928 (Digenea, Diplostomidae) em peixes do rio Paraná, Brasil. Prevalência, sazonalidade e intensidade de infecção. Acta Sci Biol Sci 2002; 24(2): 475-480.

Smith WS, Espíndola ELG, Pereira CCGF, Rocha O. Impactos dos reservatórios do médio e baixo rio Tietê na composição das espécies de peixes e na atividade de pesca. In: Espíndola EGL, Mauad FF, Schalch V, Rocha O, Felicidade N, Rietzler AC, editors. Recursos hidroenergéticos: usos, impactos e planejamento integrado. São Carlos: Rima; 2002. p. 225-241.

Takemoto RM, Pavanelli GC, Lizama MAP, Lacerda ACF, Yamada FH, Moreira LHA, et al. Diversity of parasites of fish from the Upper Paraná River floodplain, Brazil. Braz J Biol 2009;69(S2 Suppl): 691-705. PMid:19738975. http://dx.doi.org/10.1590/S1519-69842009000300023.

Tavares LER, Saad CDR, Cepeda PB, Luque JL. Larvals of Terranova sp. (Nematoda: Anisakidae) parasitic in Plagioscion squamosissimu (Perciformes: Sciaenidae) from Araguaia River, State of Tocantins, Brazil. Rev Bras Parasitol Vet 2007; 16(2): 110-115. PMid:17706015.

Tavernari FC, Bellay S, Takemoto RM, Guidelli GM, Lizama MAP, Pavanelli GC. Ecological aspects of Diplectanum piscinarius (Platyhelminthes, Monogenea) parasite of gills of Plagioscion squamosissimus (Osteichthyes, Sciaenidae) in the Upper Paraná River floodplain, Brazil. Acta Sci Biol Sci 2005; 27(3): 225-229. http://dx.doi.org/10.4025/actascibiolsci. v27i3.1279.

Thatcher VE. Brasicystis benneti n. gen., n. sp. (Trematoda: Didymozoidae) parasita da pescada (Sciaenidae) da Amazônia, Brasil. Acta Amazon 1979, 9(4): 747-749. http://dx.doi.org/10.1590/1809-43921979094747.

Thatcher VE. Rhadinorhynchus plagioscionis n. sp. (Acanthocephala: Rhadinorhynchidae) da pescada (Plagioscion squamosissimus) da Amazônia Brasileira. Acta Amazon 1980; 10(4): 835-839. http://dx.doi. org/10.1590/1809-43921980104835.

Thatcher VE. Copepods and fishes in the Brazilian Amazon. J Mar Syst 1998; 15(1-4): 97-112. http://dx.doi.org/10.1016/S0924-7963(97)00043-2.

Woo PTK. Fish diseases and disorders. Volume 1: Protozoan and Metazoan infections. 2nd ed. Oxfordshire: CABI Publishing; 2006.

Woodland WNF. Some new proteocephalids and a ptychobothriid (Cestoda) from the Amazon. J Zool 1935; 105(3): 619-623.

Yamada FH, Moreira LHA, Ceschini TL, Takemoto RM, Pavanelli GC. Novas ocorrências de metacercária de Austrodiplostomum compactum (Lutz, 
1928) (Platyhelminthes: Digenea) parasito de olhos de peixes da Bacia do Rio Paraná. Rev Bras Parasitol Vet 2008; 17(3): 163-166. PMid:19245765. http://dx.doi.org/10.1590/S1984-29612008000300010.

Zar JH. Biostatistical analysis. New Jersey: Prentice Hall Inc; 1996.
Zica EOP, Wunderlich AC, Ramos IP, Silva RJ. Austrodiplostomum compactum (Lutz, 1928) (Digenea, Diplostomidae) infecting Geophagus proximus (Castelnau, 1855) (Cichlidae, Perciformes) in the Tietê river, Nova Avanhandava reservoir, municipality of Buritama, São Paulo State, Brazil. Neotrop Helminthol 2010; 4(1): 9-15. 